\title{
4x6 poster strategy towards students' creativity and their mastery in writing at FBMB Undikma
}

\author{
Edi Firman ${ }^{1}$, M. Asrul Hasby ${ }^{2}$ \\ ${ }^{12}$ Fakultas Budaya, Manajemen, dan Bisnis \\ Email: edifirman@undikma.ac.id
}

\begin{abstract}
This research was aimed 1) To find the differences between students having high creativity and students having low creativity, 2) To identify the interaction between students' creativity and $4 x 6$ poster strategy in their writing mastery. The research was quasi experimental. In this research, represented factorial $2 X 2$ Analysis of Variant (ANOVA) design. Next to that, this research deal with the third semester of English department program with the total number was 80 students in which it was assumed that they have not creative in writing. Next to that, the data collected by using verbal creativity test and questionnaire. The techniques of data analysis was used descriptive analysis and inferential analysis. In analyzing data of the research the researcher used t-test formula. Based on the analysis, it was gotten that $t$-test score was 2.58 with the degree of freedom $(\mathrm{df})=78$ and $t$-table was 2.00 at the significant level $=0.05$ It means that the value of $t$-test was bigger than t-table. Alternative hypothesis is accepted (Ha) and Null hypothesis (Ho) is rejected. In conclusion, There is a significant effect of $4 x 6$ poster strategies towards students' creativity at FBMB UNDIKMA
\end{abstract}

Keyword: Writing Mastery, Creativity, 4x6 Poster Strategy

\begin{abstract}
Abstrak. Penelitian ini bertujuan untuk 1) mencari perbedaan antara mahasiswa yang memiliki kreatifitas tinggi dengan mahasiswa yang memiliki kreatifitas rendah, 2) mengidentifikasi interaksi antara kreatifitas mahasiswa dan strategi $4 x 6$ poster dalam kemampuan menulis mereka. Penelitian ini menggunakan penelitian eksperimental semu dengan desain Varian analisis 2X2 faktorial (ANOVA). Penelitian ini dilakukan pada mahasiswa semester tiga Program Studi Bahasa Inggris dengan jumlah populasi 80 mahasiswa dengan asumsi mereka tidak memiliki kreatifitas dalam menulis. Pengumpulan data pada penelitian ini menggunakan tes verbal kreatifitas dan angket. Tekhnik penganalisaan data menggunakan analisis deskriptif dan inferential. . Data dianalisa menggunakan rumus $t$-test. Berdasarkan hasil analisa ditemukan bahwa nilai $t$-test sebesar 2.58 dengan derajat kebebasan $(\mathrm{df})=78$ dan $t$-table sebesar 2.00 dengan tingkat signifikan $=0.05$, jadi nilai dari $t$-test lebih besar dari pada t-table, sehingga hypothesis alternative (Ha) diterima dan hypothesis nol (Ho) ditolak. Sehingga dapat disimpulkan bahwa adanya pengaruh yang signifikan dari strategi $4 x 6$ poster terhadap kreatifitas mahasiswa dalam menulis di FBMB UNDIKMA
\end{abstract}

\section{INTRODUCTION}

\section{A. Research Background}

Writing skill is the capability in using language to communicate in written form. By writing, someone is able to elaborate his/her idea and mind to get their purposes. In the same line, Heaton (1991: 6) said that "writing skill is complicated and sometime difficult to teach, requiring mastery not only of grammatical and rhetorical devise but also conceptual and judgment element".In writing skill, some difficulties often found specifically in constructing paragraph, a simple sentence or even to construct a paragraph or a composition. It is just because they tend to find out what to do first or what kinds of grammar should be usedand also in writing activity, a student should be able to utilize grammatical structure, and vocabulary.

Creativity is needed in writing, someone who has high creativity he/she will have many idea to write something. In fact, the students of FBMB UNDIKMA in the second semester they were not creative, they only write what they got from the lecturers without developed what they gotten to be more.

Based on the survey in students' final score at the second semester on English Department Students of FBMB UNDIKMA most of them were obtained the low score was less than 50 final score. Thus, all the problems above bring the researcher interested to solve the problems by offering the new strategy in teaching writing is $4 \times 6$ poster strategy to enhance 
students' creativiy in writing and writer conducts this study with the following reasons those are 1) Creativity as one of the psychological aspects plays an important role in a teaching learning process, 2) As foreign language, English is very important and it is not easy to learn it since there are many difficulties involved, 3) The result of the study can support the teachers and the students in English teaching-learning process and, 4) The result of the study can be used to know how important of creativity in learning English.

After applying the strategy the researcher hopes this strategy can be the alternative solution to solve the problem in students' writing and all the students can be more creative, flexibility or think varies idea, and develop what they got from their lecturer to be developed become new something and originality or think of unusual ideas.

Based on the problems above the researcher formulates the research questions were; (1) Are there any diferences between students having high creativity and students having low creativity?; (2) Are there any interaction between students' creativity and $4 \times 6$ poster strategy in their writing mastery?

Based on the research questions previously, the goal on this research were; (1) to find the diferences between students having high creativity and students having low creativity. (2) to indentify the interaction between students' creativity and $4 \times 6$ poster strategy in their writing mastery.

The result of this study was useful in some ways. Theoretically, it could provide information about the $4 \times 6$ poster strategy in Students' Creativity and Their Mastery in Writing . Practically, it was worth considering when people try to improve enhance the English teaching process.

\section{B. REVIEW OF LITERATURES}

1. Definition of Writing Halliday (1985b) in Nunan (1991: 84) suggests that writing has evolved in societies as a result of cultural changes creating communicative needs which cannot be readily met by the spoken language. Nunan (1991: 91) points out that writing is clearly a complex process and component writing is frequently accepted as being the last language skill to be acquired.

Richards and Renandya (2003: 303) state that writing is the most difficult skill for second language (L2) learners to master. The difficulty of writing is not only in generating and organizing ideas, but also in translating the ideas into readable text. The skills involved in writing are highly complex. L2 writers have to pay attention to higher level skills of planning and organizing as well as lower level skill of spelling, punctuation, word choice, etc. the complex writing can build the learner's ability in understanding the procedures and structural and improving their weakness vocabularies.

2. Assessing Writing

The way to assess writing it is depend on students ability and also scoring guidance of writing. According to Hughes (2003: 101-102) states there are five indicators in assessing writing they are:

1. Grammar

a. Errors of grammar or word order so severe as to make comprehension virtually impossible.

b. Errors of grammar or word order very frequent; reader has often to rely on own interpretation. 
c. Errors of grammar or word order frequent; effort of interpretation sometimes required on reader's part.

d. Errors of grammar or word order fairly frequent; occasional re-reading necessary for full comprehension.

e. Some errors of grammar or word order which do not, however, interfere with comprehension.

f. Few (if any) noticable errors of grammar or word order.

2. Vocabulary

a. Vocabulary limitations so extreme as to make comprehension virtually impossible.

b. Vocabulary so limited and so frequently misused that reader must often rely on own interpretation

c. Limited vocabulary and frequent errors clearly hinder expression of ideas.

d. Uses wrong or inappropriate words fairly frequently; expression of ideas may be limited because of inadequate vocabulary.

e. Occasionall uses inappropriate terms or relies on circumlocutions; expression of ideas hardly impaired.

f. Use of vocabulary or idiom rarely (if at all) distinguishable from taht of educated native writer.

3. Mechanics

a. Errors in spelling or punctuation so severe as to make comprehension virtually impossible.

b. Errors in spelling or punctuation so frequent that reader must often rely on own interpretation.

c. Frequent errors in spelling or punctuation; lead sometimes to obscurity

d. Errors in spelling or punctuation fairly frequent; occasional re-reading necessary for full comprehension.

e. Occasionaly lapses in punctuation or spelling which do not, however, interfere with comprehension.

4. Few (if any) noticable lapses in punctuation or spelling. Style or Eease of Communication

a. A 'hotch-potch' of halp learned misused structures and vocabulary items rendering communication almost immpossible.

b. Communication often impaired by completely inappropriate or misused ; structures or vocabulary items.

c. Structures or vocabulary items sometimes not only inappropriate but also misused; little sense of ease of communication.

d. 'Patchy', with some structures or vocabulary items noticably inappropriate to general style.

e. Occasionaly lack of consistency in choice of structures and vocabulary which does not, however, impair overall ease of communication.

f. Choice of structures and vocabulary consistency appropriate; like that of educated native writer.

5. Form (Organisation) 
a. Lack of organisation so severe that communication is seriously impaired.

b. Individualy ideas may be clear, but very difficult to deduce connection between them.

c. Little or no attempt at connectivity, though reader can deduce some organisation.

d. Some lack of organisation ; re-readig requied for clarification of ideas.

e. Material well organised; links could occasionally be clearer but communication not impaired.

f. Highly orqanised; clear progression of ideas well linked; like educated native writer.

\section{4X6 Poster Strategy}

According to Robin (2012: 13) calims that $4 \mathrm{X} 6$ Poster Strategy is the strategy that allows the teacher to differentiate by students' readiness. This strategy allows the teacher to assign tasks at the level of student without anyone in the class knowing what is going on.

To do this strategy, you will need sheets of construction paper or butcher paper. If large paper is not available, have students work on $8 \times 10$ pieces of paper and tape them together when done so the other students can browse the poster board.

It means that, before the teacher doing this strategy, the teacher must know the level of their students. Is the students in low-complexity, general level or high complexity.

\section{Procedures of Using 4X6 Poster Strategy}

Here the procedures of teaching by using 4X6 Poster strategy based on Robin (2012: 13):

a. Develop 6 tasks that represent the content you have taught. Include two tasks for students that are low complexity, two tasks for general level, and two tasks for high complexity. Do not mark the tasks in any way that will denote the complexity levels. You as the teacher will be the only one who knows this is being done. Lowerlevel tasks should have very specific directions and prompts. Be sure to include page numbers where appropriate. Higher-level tasks should be open-ended.

b. After printing out several copies of the tasks, cut them into individual strips of paper.

c. Hand each student a task suitable to her readiness level. Because there are so many different tasks, the levels will be less obvious to students than if there were only three assignments. Wander around the room as you hand out tasks, being sure to make it look like random assignments, rather than being based on ability level.

d. Assign the students to cooperative learning groups, with four students per group. Each group should be heterogeneous, with at least one student from each level represented.

e. Provide each group with a large piece of poster board or butcher paper. Direct the students to divide it into four sections and to sit around the board or paper so that they each have easy access to one section of it.

f. Have the student glue their task strip onto the top of their section of the paper. The strips will be facing in different directions. 
g. Have each student to complete his task in the space under his task strip.

h. Display the posters so that other student can browse.

4. Creativity

Rhodes (in Antonio et al, 2013: 252) defines creativity in a personal term, process and product. Creativity can be seen as a personal or individual and the surrounding that drives (or presses) the individu toward a creative behaviour. The four aspects of creativity is known as the four of creativity, person, process, press and products. This statement also supported by Zimmerer \& Scarborough in Antonio et al (2013: 252) said that reativity is defined as the ability to develop new ideas and to find new ways in opportunity creation means the ability in term of the way to express the idea and create something unusual.

1. Creativity Aspects

Starko (2010: 128) proposed four aspects of creativity to be measured, those aspects are :

a. Fluency (think of many ideas)

b. Flexibility (think of varies idea)

c. Originality (think of unusual ideas)

d. Elaboration (add to their ideas to make them better)

\section{RESEARCH METHOD}

\section{A. Research Design}

The research used quasi experimental. In this research, represents factorial $2 \mathrm{X} 2$ Analysis of Variant (ANOVA) design. Factorial design is the modification of quasi-experimental research, because it considers the existence of moderator variable which also influence the treatment of independent variable toward dependent variable. In this research, both experimental and control group were treated by using different strategies. The experimental class was taught by using $4 \times 6$ poster strategy while the control was taught by using point, illustration, explanation (PIE) strategy. To find out $4 x 6$ poster strategy was more effective than point, illustration, explanation (PIE) strategy towards students' creativity and their writing mastery and both scores were classified into high and low category.

\section{B. Research Subject}

The subjects of this research were third semester students of FBMB UNDIKMA. Two classes were chosen as the subject of this resarch those IIIa as experimental with 40 students and IIIb as control class with 40 students. So, the total number both classes were 80 students.

\section{Research Instruments}

\section{Questionnaire}

In this study, the writer used the closed questionnaire to measure the interaction between students' creativity and writing ability. This questionnaire was based on Munandar (1977: 276) who proposed an instrument to measure creativity called Creativity Attitude Scale (CAS). The questionnaire consisted of 30 statements developed from 10 indicators. The characteristics measured were 1) Having preference to do difficult and hard work, 2) Having high desire to study things, 3) Having rich knowledge, 4)Being imaginative, 5) Being open to new experiences, 6) Being brave in expressing ideas, 7) Having ability to analyze and synthesize, 8) Being selfconfident, 9) Having high initiative, and 10) Being active. Each item is followed by five closed options, namely absolutely agree (SS), agree (S), undecided (R), disagree (TS) and absolutely disagree (STS).

2. Test

The instruments of this research used verbal creativity test. Test creativity in writing purposed to measure the creativity of students in writing. The verbal creavity test based 
on the criterias the were fluency, flexibility, originality, and elaboration.

\section{Techniques of Data Collection}

1. Questionnaire

The writer collected the data of students' interaction between their creativity and writing ability by using questionnaire.

2. Verbal Creativity Test

The data collected by using two steps of test, they were:

a. Pre-test

The functional usage of pretest was to collect the participants' primary data with reference to writing skill. This pretest was administered before treatments

b. Post-test

Posttest was a test given to the experimental and control groups after completion of treatments to measures the effectiveness of treatments.

\section{E. Techniques of Data Analysis}

\section{Questionnaire}

The questionnaire was analyzed by using Creative Attitude Scale (CAS). To score the scale, the response options was credited 5, 4, 3, 2, and 1 from absolutely agree to absolutely disagree statements. The writer used the percentage description analysis to measure of the students' creativity . The formula used was as follows:

$$
\begin{array}{clc}
\multirow{2}{*}{\begin{array}{c}
\text { The } \\
\text { Percentage }
\end{array}} & \begin{array}{l}
\text { The Total Value } \\
\text { of Answer }
\end{array} & \mathrm{x} \\
& \begin{array}{l}
\text { The Total Value } \\
\text { 10 Ideal Answer }
\end{array} & \\
\text { (Arikunto, 2010: 244) }
\end{array}
$$

Then, the writer categorized the scores resulted from calculation into the following criteria:

Table 3.1. the measurement of students' creativity achievement

\begin{tabular}{|l|l|}
\hline \multicolumn{1}{|c|}{ Criteria } & Percentage \\
\hline Very High & $84 \%-100 \%$ \\
\hline High & $68 \%-83 \%$ \\
\hline Fair & $52 \%-67 \%$ \\
\hline
\end{tabular}

\begin{tabular}{|l|l|}
\hline Low & $36 \%-51 \%$ \\
\hline Very Low & $20 \%-35 \%$ \\
\hline
\end{tabular}

(Yohanes, 1998:74 quoted by Miswadi 2000:54)

2. Verbal Creativity Test

Here, the measurement of students' creativity in writing show in following table below:

Table 3.2. the measurement of students' creativity achievement

\begin{tabular}{|l|l|}
\hline Criteria of mastery & Grade \\
\hline $85-100$ & Excelent \\
\hline $68-84$ & Good \\
\hline $60-67$ & Fair \\
\hline $45-59$ & Poor \\
\hline$<45$ & Fail \\
\hline
\end{tabular}

3. Descriptive Analysis

There were some measurement analyze in this discipline; frequency distribution, central tendency that comprise: mean, mode, median, variant and standard deviation. In analyze the uses Microsoft Excel 2010 as a mounting tool

4. Inferential Analysis

In order to analyze the research data, the most appropriate statistical procedure to be employed in this research is 2 X 2 ANOVA (Analysis of Variance). There were some requirements have to be fulfilled before the analysis could be executed, namely testing for normal distribution, testing for homogeneity of variance, and finally was testing for hypothesis. The tool of analysis data on this context is Microsoft Excel 2010 and SPSS 16.0 as mounting tools.

a. Normality

Normality test was carried out to identify whether the data was normally distributed or vice versa. In order to analyze the data normality, Shapiro Wilk formula was applied and SPSS 16 ® used as the tool of data analysis.

b. Homogeneity of Variance 
The purpose of homogeneity test was to analyze the research data or examine the existing hypotheses

\section{RESEARCH FINDING AND OUTCOME}

\section{A. Research Finding}

\section{The Result of Pre-Test}

The data showed that, the highest score of pre-test was 60 and the lowest score was 40 , after the researcher calculating the score of pre-test by using descriptive analysis, the researcher found that the result of mean was 54,78 , median was 55,75 , mode was 56,07, and the standard deviation was 137,96 .

Histogram and Polygon of Control Group

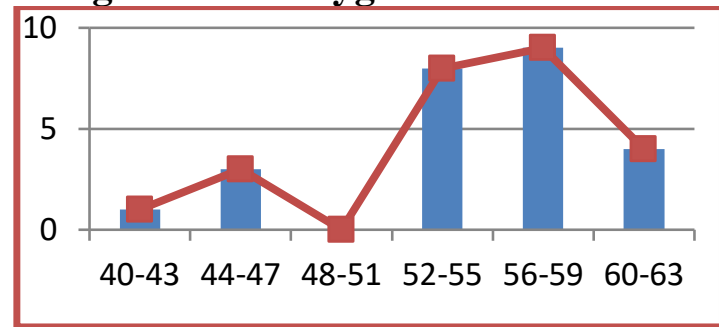

The graphic above is use for convey the data from Pre-test of students in writing skill, it also use for the viewers in pictorial form or to describe the data set. It is easier for most people to comprehend the meaning of data presented as a picture then data presented as a table, this is especially true if the viewers have little or no statistical knowledge.

\section{The result of post-test}

The data showed that, the highest score of post-test was 76 and the lowest score was 40, after the researcher calculating the score of posttest by using descriptive analysis, the researcher found that the result of mean was 65,26 , median was 70,5 , mode was 79,5 , and the standard deviation was 165,34 .
Histogram and Polygon of Experimental Group

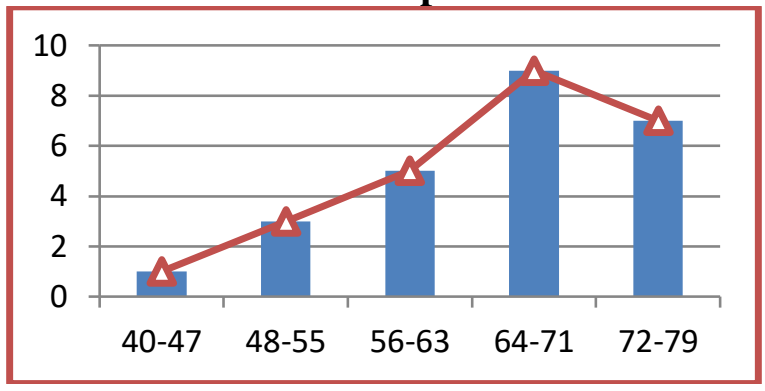

The graphic above is use for convey the data from Post-test of students in writing skill, it also use for the viewers in pictorial form or to describe the data set. It is easier for most people to comprehend the meaning of data presented as a picture then data presented as a table, this is especially true if the viewers have little or no statistical knowledge.

\section{CONCLUSION}

\section{A. Research Conclusion}

From the elaboration of the research findings, the researchers could conclude that the students were interest to write after aplying the $4 \times 6$ strategy should cover the whole objectives and three topics interest with the settled teachers and students' role.

\section{REFERENCES}

Anas Sudijono. 2007. Pengantar Statistik Pendidikan. Jakarta. PT. RajaGrafindo Persada

Antonio, T., Lanawati, S., Wiriana, T.A., Christiana, L. (2013). Correlations Creativity, Intelligence, Personality, and Enterpreneurship Achievement.Procedia, 6, 252.

Evi Susiwati. 2015. The Effectiveness Of Point, Illustration, Explanation (Pie) Strategy On Students' Creativity In Writing. Unpublished Thesis,. IKIP MATARAM. 
Heaton, J. B. 1991. Writing English Language Test. London: Longman Group Limited

Hughes, A. 2003. Testing for Language Teachers. United Kingdom. Cambridge

Marczyk, G., DeMatteo, D., Festinger, D. 2005. Essentials of Research Design and Methodology. Canada: John Willey \& Sons Inc.

Munandar, U. 1999. Creativity and Education. Universitas Sebelas Maret. Proyek

Pengadaan/Penterjemah Buku Direktorat pembinaan Penelitian dan Pengabdian pada Masyarakat Direktorat Pendidikan Tinggi Departemen Pendidikan dan Kebudayaan.

Nunan, D. 1991. Language Teaching Methodology: A textbook for teacher. New York: Prentice Hall International. Ltd

Oshima, A., \& Hogue, A. 1999. Writing Academic English (3rd ed). London: Pearson Education, Inc

Raimes, Aan. 1978. Focus on Composition. New York: Oxford University Press, Inc.

Richards, J. C., \& Renandya, W. A. 2003. Methodology in Language Teaching: An Anthology of Current Practice. New York: Cambridge University Press.

Robin C. Letendre. 2012. 101 Learning Strategy. Learning Disabilities consultant Mentor Teacher Reading Specialist.

Starko, Jordan, Alane. 2010. Creativity in the Classroom. Schools of Curious Delight 4th Edition. New York and London. Routledge.

Zunianti. 2016. The Effect of $4 X 6$ Poster strategy towards students' speaking skill at the second grade students of MTs. Nurul Wathan NW Plambik. Unpublished Thesis,. IKIP MATARAM 